\title{
Phormium Yellow Leaf Phytoplasma Is Associated with Strawberry Lethal Yellows Disease in New Zealand
}

\author{
M. T. Andersen, J. Longmore, L. W. Liefting, G. A. Wood, P. W. Sutherland, D. L. Beck, and R. L. S. Forster, \\ The Horticulture and Food Research Institute of New Zealand Ltd., Private Bag 92169, Auckland, New Zealand
}

\begin{abstract}
Andersen, M. T., Longmore, J., Liefting, L. W., Wood, G. A., Sutherland, P. W., Beck, D. L., and Forster, R. L. S. 1998. Phormium yellow leaf phytoplasma is associated with strawberry lethal yellows disease in New Zealand. Plant Dis. 82:606-609.

A yellows disease of strawberry plants was identified in propagation beds in New Zealand. Affected plants were flatter to the ground, showed purpling of older leaves, reduced leaf size, yellowing of younger leaves, and sometimes plant death. A phytoplasma was observed in the phloem of affected plants. The 16S rRNA gene of the phytoplasma was amplified by polymerase chain reaction from symptomatic plants and from one asymptomatic plant, but not from 36 other asymptomatic plants. Nucleotide sequence analysis of the 16S rRNA gene showed that the phytoplasma is closely related or identical to the phytoplasma associated with the yellow leaf disease of New Zealand flax (Phormium tenax).
\end{abstract}

A number of diseases ascribed to phytoplasmas, rickettsialike (16), and bacterialike (23) organisms have been reported infecting strawberry plants worldwide. The most comprehensively reported phytoplasmas include aster yellows (6) and strawberry green petal $(17,18,28)$. Other diseases in which phytoplasmas have been implicated include bronze leaf wilt (7), lethal decline (30), lethal yellows-mycoplasma yellows $(15,16,34)$, big bud-little leaf (32), multiplier disease, and witches'broom $(8,27)$.

Of these diseases, strawberry green petal has been reported in New Zealand (2). In addition, a yellows-type disorder has been reported in runner beds propagated by specialist growers in the Katikati district, Bay of Plenty (26). Affected plants of cvs. Douglas and Tioga characteristically lacked vigor in the field. Under glasshouse conditions, affected plants rapidly degenerated, resulting in premature death (25). The disorder was shown by electron microscopy to be associated with a phytoplasma (26), but the identity of the phytoplasma was not determined. Despite changes

Corresponding author: Mark Andersen

E-mail: mandersen@Hort.cri.nz

Funds for this research were provided by The Foundation for Research Science and Technology, Lottery Science Research, and the New Zealand Berryfruit Propagators Ltd.

Accepted for publication 9 February 1998.

Publication no. D-1998-0424-01R

(C) 1998 The American Phytopathological Society in strawberry cultivars (cv. Pajaro is currently preferred in New Zealand), the yellows disorder still occurs in runner beds.

This study shows that the symptoms of the yellows disorder in New Zealand are most similar to the mycoplasma yellows and lethal yellows disorders described in strawberries in Australia (16,32,34). We also show that the phytoplasma associated with the disease in New Zealand is closely related to, or identical to, the phytoplasmas associated with phormium yellow leaf (PYL), Australian grapevine yellows, and papaya dieback.

\section{MATERIALS AND METHODS}

Source of plants. Sixteen strawberry plants of cv. Pajaro were obtained from runner beds, of which 7 were symptomatic, 8 were asymptomatic, and 1 showed slight reddening of the outer leaves, possibly representing an early stage of infection. Twenty-nine asymptomatic, nuclear stock plants from meshed, insect-free greenhouses also were tested.

Electron microscopy. The petiole of strawberry plants was cut into 5-mm pieces and fixed in $2 \%$ freshly prepared paraformaldehye and $2.5 \%$ glutataldehyde in 0.1 $\mathrm{M}$ phosphate buffer at $\mathrm{pH} 7.2$ under vacuum for $1 \mathrm{~h}$. The samples were then washed three times in buffer, post-fixed in $1 \%$ osmium tetroxide for $1 \mathrm{~h}$, dehydrated in an ethanol series, infiltrated, and embedded in Spurr's resin. The phloem region of the petiole was sectioned and stained in aqueous uranyl acetate and lead citrate. Sections were viewed on a JEM-1200EX II transmission electron microscope (JEOL, Tokyo) operating at $80 \mathrm{kV}$.
Extraction of nucleic acid from plants. DNA was extracted from plant tissue by modification of the "hot cetyltrimethylammonium bromide (CTAB)" method of Doyle \& Doyle (10), combined with a high salt ethanol precipitation step (11). Approximately $1 \mathrm{~g}$ tissue was frozen in liquid nitrogen, then ground in a prechilled mortar and pestle. The powdered tissue was incubated in $10 \mathrm{ml}$ pre-heated extraction buffer $(0.14 \mathrm{M}$ sorbitol, $0.22 \mathrm{M}$ TrisHCl pH 8.0, 22 mM EDTA pH 8.0, 0.8 $\mathrm{M} \mathrm{NaCl}, 0.8 \%$ wt/vol CTAB, $1 \%$ N-lauryl sarcosine) and incubated for 20 to $30 \mathrm{~min}$ at $65^{\circ} \mathrm{C}$ with occasional shaking. Samples were extracted twice with equal volumes of phenol and chloroform, and once with an equal volume of chloroform. $\mathrm{NaCl}$ was added to a final concentration of $2 \mathrm{M}$. Two volumes of ethanol were added and samples were kept at $-20^{\circ} \mathrm{C}$ overnight. Samples were centrifuged at $7,500 \times g$ for 20 $\min \left(4^{\circ} \mathrm{C}\right)$, and the pellet washed with $2 \mathrm{ml}$ $70 \%$ ethanol and dried under vacuum for 5 to $10 \mathrm{~min}$. DNA pellets were resuspended in $1.0 \mathrm{ml}$ distilled water.

Polymerase chain reaction. Primers used in this study are listed in Table 1. Primers R16F2 and R16R2 (20), and NGF, NGR, and NP6A (21) were designed to be "universal" phytoplasma primers. Primers M1 and M3 (21) were designed to be specific to the phytoplasmas associated with PYL, Australian grapevine yellows, and papaya dieback diseases. Primers Gd1 and Berg 54 (1) and R4 (21) were designed to be universal prokaryotic 16S rRNA gene primers. Primers Gd1 and Berg54 amplified products from both healthy and infected plants, and were used to establish the polymerase chain reaction (PCR) competence of each DNA sample.

Each PCR reaction contained $50 \mathrm{mM}$ Tris- $\mathrm{HCl} \mathrm{pH}$ 9.0, $20 \mathrm{mM}$ ammonium sulfate, and $2.5 \mathrm{mM} \mathrm{MgCl}_{2}$. Template DNA was used at 10 to $50 \mathrm{ng}$ for single-step PCR reactions. For nested PCR, products of the primary amplification step were diluted 1:25 prior to reamplification. Primers were used at a concentration of $400 \mathrm{nM}$. Amplification involved an initial denaturation at $94^{\circ} \mathrm{C}$ for $2 \mathrm{~min}$ followed by 35 cycles of $94^{\circ} \mathrm{C}, 30 \mathrm{~s} ; 55^{\circ} \mathrm{C}, 15 \mathrm{~s}$; and $72^{\circ} \mathrm{C}, 1 \mathrm{~min}$ in a Corbett FTS-1S Capillary Thermal Sequencer. All sets of reactions included DNA samples from 
healthy plants and controls lacking template DNA.

Analysis of PCR amplification products. PCR products were analyzed by electrophoresis on $1.5 \%$ agarose gels in $1 \times$ Tris-borate-EDTA (TBE) buffer $(67 \mathrm{mM}$ Tris-HCl; $22 \mathrm{mM}$ boric acid; $1 \mathrm{mM}$ EDTA,
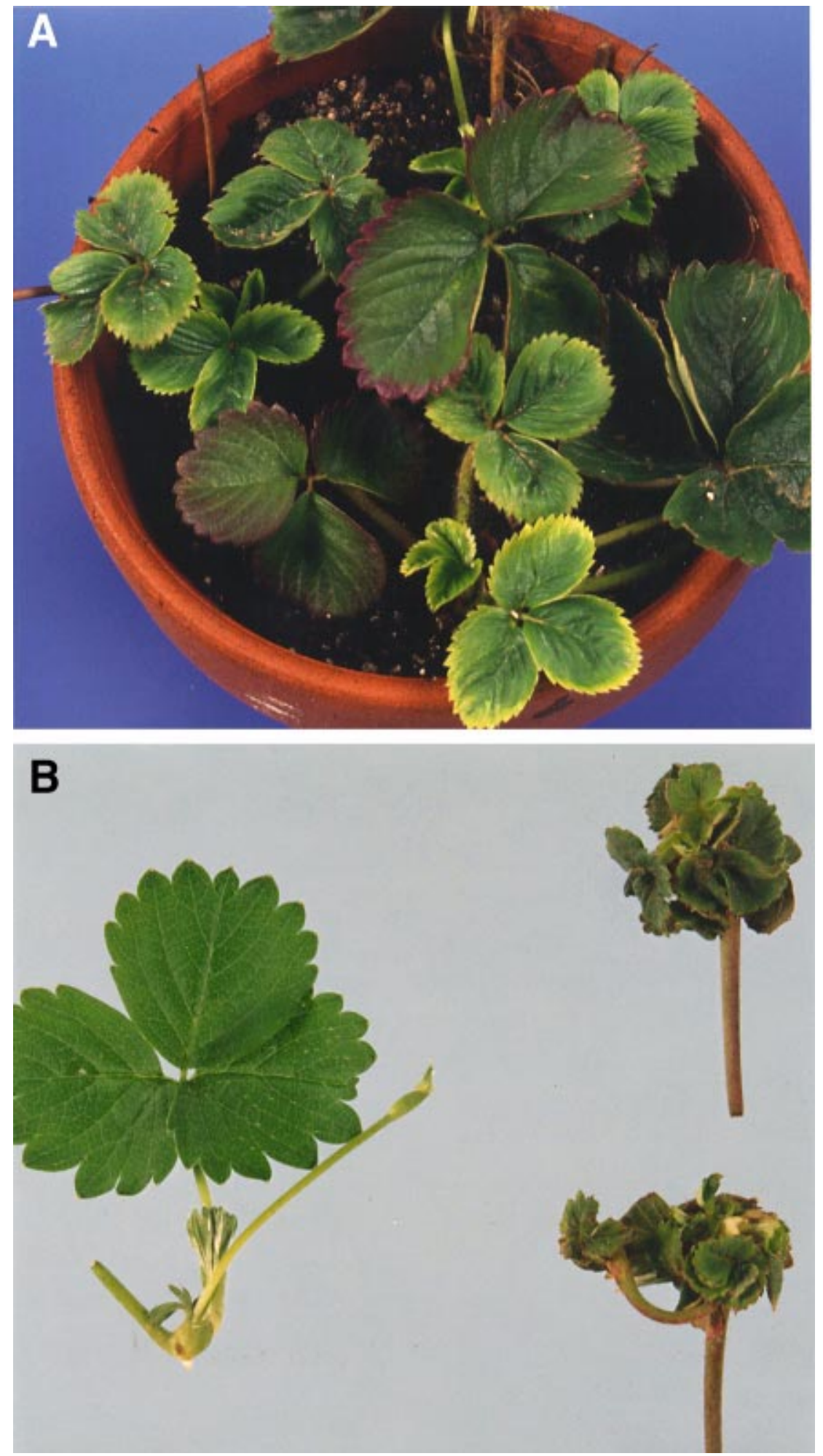

Fig 1. Symptoms of strawberry lethal yellows on cv. Pajaro. (A) The older leaves display purplebronzing and the younger leaves show a pronounced marginal chlorosis. (B) Characteristic symptoms on leaves of stoloniferous plants. Leaves are twisted and curled into rosettes. A healthy sample is shown for comparison (left).
Sequencer. PCR for DNA sequencing was performed in an ERICOMP Easy with the following conditions: $94^{\circ} \mathrm{C} 1 \mathrm{~min}$, one cycle; $95^{\circ} \mathrm{C} 30 \mathrm{~s}, 50^{\circ} \mathrm{C} 15 \mathrm{~s}, 60^{\circ} \mathrm{C} 4 \mathrm{~min}$, for 25 cycles; $95^{\circ} \mathrm{C} 30 \mathrm{~s}, 50^{\circ} \mathrm{C} 3 \mathrm{~min}$, for 15 cycles; then $60^{\circ} \mathrm{C} 10 \mathrm{~min}$ for one cycle.

\section{RESULTS}

Field symptoms. Infected plants became readily apparent in the field: they were flatter to the ground than adjacent healthy plants and their foliage growth more open. As the disease progressed, the older leaves became purple-bronze in color, particularly toward the margin. Young leaves were smaller than normal, with shortened petioles and a conspicuous chlorosis, initially occurring around the leaf margin, but later covering much of the leaf area (Fig. 1A). The production of flowers and fruit was inhibited, although flowers and fruit which did develop were not distorted. Leaves on runners were small, curled, and twisted, light yellow in color, and formed rosettes (Fig. 1B). The disease was sometimes lethal, although plants often remained alive but failed to make any significant growth.

Electron microscopy. Electron microscopy was undertaken to confirm the association reported by Patel and Milne (26) between disease symptoms and presence of a phytoplasma. In our study and in the study by Patel and Milne (26), phytoplasmas were observed in immature and mature sieve cells (Fig. 2). In some cells, large concentrations of phytoplasmas were observed, while in other cells the phytoplasmas were mainly concentrated along cell walls. Five structural categories of phytoplasmas, elementary bodies, intermediate and filamentous forms, mature cells, and budding cells were observed as reported elsewhere (33). Filamentous forms were usually observed near sieve plate pores, as reported in other studies $(3,31)$.

PCR amplification of the $16 \mathrm{~S}$ rRNA gene. A PCR product of 1.6 kilobase $(\mathrm{kb})$ was amplified from each strawberry plant using the universal $16 \mathrm{~S}$ rRNA primers Gd1 and Berg 54, indicating that all DNA samples were competent for PCR. Products of approximately 500 base pairs (bp) were obtained by nested PCR from 7 symptomatic plants using the phytoplasma-specific primers R16F2-R16R2, and NGFNGR (Fig 3A). PCR products were also amplified from a plant showing slight reddening of the outer leaves and from an asymptomatic plant, presumably indicating that both were at an early stage of infection. PCR products were not obtained from 8 other asymptomatic plants from the field or from 29 nuclear stock plants. All plants which tested positive using the phytoplasma-specific primers also tested positive with the PYL-specific primers M1 to M3 (Fig 3B)

Nucleotide sequence. Nucleotide sequence analysis of a 713-bp fragment am- 
plified from a diseased strawberry plant using primers R4-NP6A revealed nucleotide polymorphisms at positions 1151 $(\mathrm{C} / \mathrm{T})$ and 1432 (A/G) (numbering according to Liefting et al.; 21). At all other positions, the nucleotide sequence of the PCR product was identical to that of PYL. The two polymorphisms correspond to the differences between operons $r r n A$ and $r r n B$ of PYL phytoplasma (21). Based on these results, we conclude that strawberry lethal yellows and PYL phytoplasma are either closely related or identical.

\section{DISCUSSION}

Our results confirm the earlier studies of Patel and Milne (26) that the yellows disease of New Zealand strawberry is probably caused by a phytoplasma. Further, our results show that the phytoplasma is closely related, or identical, to PYL, a phytoplasma previously recorded in New Zealand only in New Zealand flax (Phormium tenax, P. cookianum; 5). PYL disease was first recorded in New Zealand in 1908, and it contributed to the eventual demise of the once-thriving fiber industry based on New Zealand flax (5). PYL phytoplasma is transmitted by the mono- phagous cixid plant hopper Oliarus atkinsoni, a species occurring only in New Zealand. Nymphs of this hopper develop in the rhizomous regions of the plant; this is the region in New Zealand flax plants with the highest concentrations of phytoplasma (35). This close association, and the existence of tolerant forms of $P$. tenax, suggest a long association between phytoplasma, host, and vector (4). The narrow host range of $O$. atkinsoni suggest that another insect species is involved in the spread of PYL into strawberry. Two possible candidates, the bramble leafhopper Ribautiana tenerrima (Herrich-Schaeffer) and the yellow pasture leafhopper Zygina zealandica (Myers), have been observed on strawberry in New Zealand (25).

The symptoms on strawberry in New Zealand show some similarities to those associated with strawberry lethal decline in North America (30). Lethal decline is possibly associated with peach X-disease (12). However, peach $\mathrm{X}$-disease, a serious disease of stone fruits in North America $(14,19)$, has not been recorded in stone fruit in New Zealand (37), and the peach $\mathrm{X}$-disease phytoplasma is taxonomically distinct from PYL phytoplasma (21). It

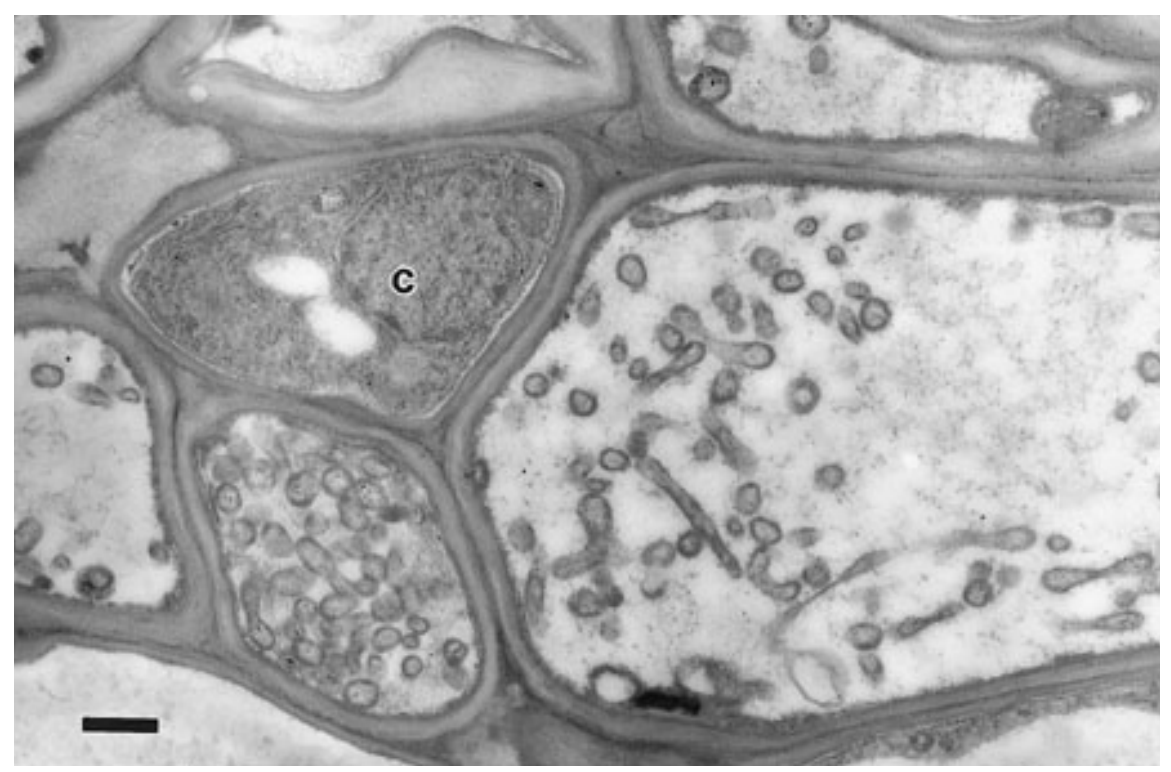

Fig 2. Transmission electron micrograph of strawberry phloem tissue infected with pleomorphic phytoplasmas. "C" indicates the phloem companion cell. The bar represents $500 \mathrm{~nm}$.

seems unlikely, therefore, that strawberry lethal yellows and strawberry lethal decline are the same disease.

The symptoms of the yellows disease in New Zealand appear to most closely resemble those described in strawberries in Australia for three similar or identical diseases, mycoplasma yellows (16), lethal yellows (34), and little leaf disease (32). There is a high degree of nucleotide sequence homology between the phytoplasmas associated with PYL in New Zealand and the phytoplasmas associated with Australian grapevine yellows and papaya dieback in Australia $(13,24,36)$. On this basis, we have proposed that all three diseases may be caused by the same phytoplasma (Liefting et al, unpublished). The name "Candidatus Phytoplasma aus-

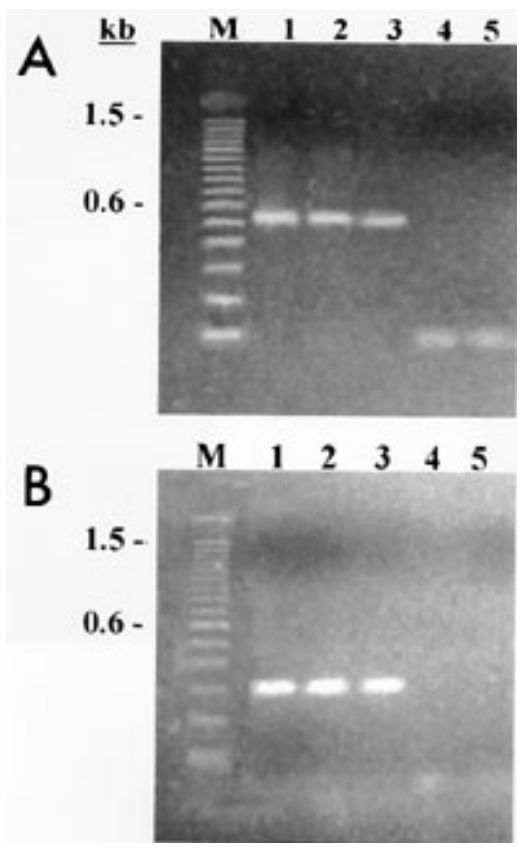

Fig. 3. Agarose gel (1.5\%) electrophoresis of nested-polymerase chain reaction (PCR) products of (lanes 1-3) three infected and (lanes 4 and 5) two healthy strawberry plants amplified using nested-PCR. The universal phytoplasma primers R16F2-R16R2 were used for the primary amplification step, and universal phytoplasma primers (A) NGF-NGR or (B) "Candidatus Phytoplasma australiense" groupspecific primers M1-M3 for the re-amplification step. Marker (M) was 100-base pair ladder (Life Technologies).

Table 1. List of primers for polymerase chain reaction

\begin{tabular}{lrrr}
\hline Primer name & Sequence $\left(\mathbf{5}^{\prime} \mathbf{~ 3}^{\prime}\right.$ ) & Position $^{\mathbf{a}}$ & Reference \\
\hline Gd1 & ACG GAG AGT TTG ATC CTG & $3 \rightarrow 20$ & 1 \\
Berg54 & AAA GGA GGT GAT CCA GCC GCA CCT TC & $1535 \rightarrow 1510$ & 1 \\
R16F2 & ACG ACT GCT AAG ACT GG & $152 \rightarrow 168$ & 20 \\
R16R2 & TGA CGG GCC GTG TGT ACA AAC CCC G & $1397 \rightarrow 1373$ & 20 \\
NGF & AGG CGG CTT GCT GGG TCT T & $725 \rightarrow 743$ & 21 \\
NGR & AGC CAT TGT ATC ACG TT & $1231 \rightarrow 1215$ & 21 \\
M1 & GAA GGC ATC TTT TTA TC & $182 \rightarrow 198$ & 21 \\
M3 & GTA CCG TCA TAA TGG & $485 \rightarrow 471$ & 21 \\
R4 & GGG TTA AGT CCC GCA ACG AG & $1073 \rightarrow 1092$ & 21 \\
NP6A & TTA CGA CTT AAC CCC AA & $1490 \rightarrow 1473$ & 21 \\
\hline
\end{tabular}

a Positions based on the sequence of the phytoplasma associated with phyllody of Oenothera hookeri (22). 
traliense" has been proposed for this phytoplasma (9). In view of the fact that similar or identical phytoplasmas occur in both Australia and New Zealand, it is possible that the yellows diseases of strawberry in both countries are also caused by the same phytoplasma. As infected plants develop a yellows disease, and as the disease is often lethal, we have used the name strawberry lethal yellows, first proposed by Stubbs (34), to describe the disease in New Zealand.

The lethal yellows diseases in both Australia and New Zealand are currently managed by roguing of diseased plants (15). In propagation beds in New Zealand, infection levels are usually less than $10 \%$, and infected plants are predominantly found around the perimeter of blocks. This suggests that further spread through blocks is restricted by current insecticide spray regimes. A knowledge of the vector(s) and alternate hosts may further assist in control.

\section{ACKNOWLEDGMENTS}

We thank D. W. Mossop for supplying plants.

\section{LITERATURE CITED}

1. Andersen, M. T., Beever, R. E., Gilman, A. C., Liefting, L. W., Balmori, E., Beck, D. L., Sutherland, P. W., Bryan, G. T., Gardner, R. C., and Forster, R. L. S. Detection of phormium yellow leaf phytoplasma in New Zealand flax (Phormium tenax) using nested PCR. Plant Pathol. In press.

2. Anonymous. 1991. Strawberry green petal disease mycoplasma-like organism. DSIR Guide to identification of insects, mites, and diseases of strawberry. Auckland Berryfruit Growers Assn. (Inc)., Auckland, New Zealand.

3. Beakbane, B., Mishra, M. D., Posnette, A. F., and Slater, C. H. W. 1971. Mycoplasma-like organisms associated with chat fruit and rubbery wood diseases of apple, Malus domestica Bork., compared with those in strawberry with green petal disease. J. Gen. Microbiol. 66:55-62.

4. Boyce, W. R. 1958. Resistance to yellow-leaf disease of Phormium tenax Forst. and the occurrence of delayed expression of symptoms. N. Z. J. Agric. Res. 1:31-36.

5. Boyce, W. R., and Newhook, F. J. 1953. Investigations into yellow-leaf disease of Phormium. I. History and symptomatology. N. Z. J. Sci. Technol. 34A (Suppl. 1):1-11.

6. Chiykowski, L. N. 1987. Aster yellows in strawberry. Pages 31-34 in: Virus Diseases of Small Fruits. R. H. Converse, ed. U. S. Dep. Agric. Agric. Handb. No. 631.

7. Chiykowski, L. N., and Posnette, A. F. 1987. Other leafhopper-borne diseases of straw- berry. Page 45 in: Virus Diseases of Small Fruits. R. H. Converse, ed. U. S. Dep. Agric. Agric. Handb. No. 631.

8. Converse, R. H. 1987. Strawberry witches'broom and multiplier diseases. Pages 66-68 in: Virus Diseases of Small Fruits. R. H. Converse, ed. U. S. Dep. Agric. Agric. Handb. No. 631 .

9. Davis, R. E., Dally, E. L., Gundersen, D. E., Lee, I.-M., and Habili, N. 1997. "Candidatus Phytoplasma australiense," a new phytoplasma taxon associated with Australian grapevine yellows. Int. J. Syst. Bacteriol. 47:262-269.

10. Doyle, J. J., and Doyle, J. L. 1990. Isolation of plant DNA from fresh tissue. Focus (Life Technologies Inc.) 12:13-15.

11. Fang, G., Hammar, S., and Grumet, R. 1992. A quick and inexpensive method for removing polysaccharides from plant genomic DNA. BioTechniques 13:52-56

12. Frazier, N. W., and Jensen, D. D. 1970. Strawberry, an experimental host of peach Western X-disease. Phytopathology 60:15271528.

13. Gibb, K. S., Persley, D. M., Schneider, B., and Thomas, J. E. 1996. Phytoplasmas associated with papaya diseases in Australia. Plant Dis. 80:174-178.

14. Gilmer, R. M., and Blodgett, E. C. 1976. Xdisease. Pages 145-155 in: Virus Diseases and Noninfectious Disorders of Stone Fruit in North America. Pine, T., ed. U. S. Dep. Agric. Agric. Handb. No. 537.

15. Greber, R. S. 1987. Strawberry ricksettsia yellows and mycoplasma yellows. Pages 4145 in: Virus Diseases of Small Fruits. R. H. Converse, ed. U. S. Dep. Agric. Agric. Handb. No. 631.

16. Greber, R. S., and Gowanlock, D. H. 1979. Rickettsia-like and mycoplasma-like organisms associated with two yellows-type diseases of strawberries in Queensland. Aust. J. Agric. Res. 30:1101-1109.

17. Harrison, N. A., Legard, D. E., DiBonito, R., and Richardson, P. A. 1997. Detection and differentiation of phytoplasmas associated with diseases of strawberry in Florida. Plant Dis. 81:230.

18. Honetšlegrová, J. F., Vibio, M., and Bertaccini, A. 1996. Electron microscopy and molecular identification of phytoplasmas associated with strawberry green petals in the Czech Republic. Eur. J. Plant Pathol. 102:831-835

19. Kirkpatrick, B. C., Ugemoto, J. K., Purcell, A. H. 1995. X-disease. Pages 57-59 in: Compendium of Stone Fruit Diseases. APS Press, St. Paul, MN.

20. Lee, I.-M., Hammond, R. W., Davis, R. E., and Gundersen, D. E. 1993. Universal amplification and analysis of pathogen 16S DNA for classification and identification of mycoplasmalike organisms. Phytopathology 83:834-842.

21. Liefting, L. W., Andersen, M. T., Beever, R. E., Gardner, R. C., and Forster R. L. S. 1996. Sequence heterogeneity in the two 16S rRNA genes of Phormium yellow leaf phytoplasma.
Appl. Environ. Microbiol. 62:3133-3139.

22. Lim, P.-O., and Sears, B. B. 1989. 16S rRNA sequence indicates that plant-pathogenic mycoplasmalike organisms are evolutionarily distinct from animal mycoplasmas. J. Bacteriol. 171:5901-5906.

23. Nourrisseau, J. G., Lansac, M., and Garnier, M. 1993. Marginal chlorosis, a new disease of strawberries associated with a bacterium-like organism. Plant Dis. 77:1055-1059.

24. Padovan, A. C., Gibb, K. S., Daire, X., and Boudon-Padieu, E. 1996. A comparison of the phytoplasma associated with Australian grapevine yellows to other phytoplasmas in grapevine. Vitis 35:189-194.

25. Patel, N. P. 1985. Virus and virus-like disease of strawberry. Dissertation for Dep. Hortic. Sci. Massey University. Palmerston North, N Z.

26. Patel, N. P., and Milne, K. S. 1985. About strawberry viruses. N. Z. Fruit Produce J. 6:49

27. Pisi, A., and Vicchi, V. 1989. Mycoplasmalike organisms in different strawberry varieties in the Emilia-Romagna region, Italy. Acta Hortic. 265:615-618

28. Posnette, A. F., and Chiykowski, L. N. 1987. Strawberry green petal and similar diseases. Pages 34-38 in: Virus Diseases of Small Fruits. R. H. Converse, ed. U. S. Dep. Agric. Agric. Handb. No. 631

29. Sambrook, J., Fritsch, E. F., and Maniatis, T. A. 1989. Molecular Cloning: A Laboratory Manual. 2nd ed. Cold Spring Harbor Laboratory, Cold Spring Harbor, NY

30. Schwartze, C. D., Frazier, N. W., and Converse, R. H. 1987. Strawberry lethal decline. Pages 38-41 in: Virus Diseases of Small Fruits. R. H. Converse, ed. U. S. Dep. Agric. Agric. Handb. No. 631

31. Seliskar, C. E., Wilson, C. L., and Bourne, C. E. 1972. Mycoplasma-like bodies found in phloem of black locust affected with witches' broom. Phytopathology 63:30-34.

32. Shanmuganathan, N., and Garrett, R. G. 1976. Little leaf of strawberry. (Abstr.) Aust. Plant Pathol. Soc. Newsl. 5 (Suppl). 83.

33. Sinha, R. C., and Paliwall, Y. C. 1969. Association, development and growth cycle of mycoplasma-like organisms in plants affected with clover phyllody. Virology 39:759-767.

34. Stubbs, L. L. 1968: Lethal yellows disease of strawberry. Aust. Plant. Dis. Rec. 20:33-34.

35. Ushiyama, R., Bullivant, S., and Matthews, R. E. F. 1969. A mycoplasma-like organism associated with phormium yellow leaf disease. N. Z. J. Bot. 7:363-371.

36. White, D. T., Billington, S. J., Walsh, K. B., and Scott, P. T. 1997. DNA sequence analysis supports the association of phytoplasmas with papaya (Carica papaya) dieback, yellow crinkle and mosaic. Australas. Plant Pathol. 26:28-36

37. Wood, G. A. 1979. Health check on imported cultivars and rootstocks. Virus and virus-like diseases of pomefruits and stone fruits in New Zealand, N.Z. Dep. Sci. Ind. Res. Bull. No. 226:20. 